\title{
Early Triassic microbialites from the Changxing Region of Zhejiang Province, South China
}

\author{
Ya-Fei Huang ${ }^{1}$, David P. G. Bond ${ }^{2}$, Yong-Biao Wang ${ }^{1 *}$, Tan Wang ${ }^{1}$, Zhi-Xing Yi ${ }^{1}$, Ai-Hua Yuan ${ }^{1}$, Jia-Yuan Jia ${ }^{1}$ and \\ Yu-Qi Su ${ }^{1}$
}

\begin{abstract}
Microbialites, often considered as a signal of extreme marine environment, are common in the Lower Triassic strata of South China where they flourished in the aftermath of the end-Permian mass extinction. Early Triassic microbialite facies are known to vary palaeogeographically, perhaps due to differing climates, ocean chemistry, and water depths. This paper provides the first record of a brief, but spectacular development of microbialites in the aftermath of the end-Permian mass extinction at Panjiazhuang section, Changxing Region of Zhejiang Province (eastern South China). Here, the Upper Permian Changxing Formation comprises typical shallow platform facies rich in calcareous algae and foraminifera, the development of which was terminated by the major end-Permian regression. A 3.4-m-thick microbialite began to form at the onset of the transgression in the earliest Triassic. The microbialite at Panjiazhuang section is composed of thrombolite that contains abundant calcified cyanobacteria, small gastropods, microconchid tubes and ostracods, representing a low-diversity shallow marine community in the aftermath of the end-Permian crisis. The microbialites are succeeded by thin-bedded micrites bearing thin-shelled bivalves, which record a rapid sea-level rise in the Early Triassic. Abundant populations of small pyrite framboids are observed in the upper part of the microbialites and the overlying thin-bedded micrites, suggesting that dysoxic water conditions developed at that time. The appearance of microbialites near the Permian-Triassic boundary (PTB) at Panjiazhuang section was the result of peculiar marine conditions following the end-Permian regression, whilst their disappearance was due to the increasing water depth and the development of dysoxia.
\end{abstract}

Keywords: Microbialites, Regression, Transgression, Anoxia, Early Triassic, Changxing, Zhejiang Province

\section{Introduction}

The end-Permian mass extinction was a result of catastrophic changes in terrestrial (Benton and Newell 2014; Hochuli et al. 2017) and marine (Chen and Benton 2012; Payne and Clapham 2012; Yin et al. 2012; Song et al. 2013) environments. The latest Permian is also associated with a major, global regression (Newell 1967; Hallam and Wignall 1999; Heydari et al. 2003; Wu et al. 2010; Farabegoli and Perri 2012; Yin et al. 2014), which was succeeded by a transgression and drowning of emergent platforms during the Early Triassic. The associated changes in marine

\footnotetext{
*Correspondence: wangyb@cug.edu.cn

${ }^{1}$ State Key Laboratory of Geological Processes and Mineral Resources, School of Earth Sciences, China University of Geosciences (Wuhan), Wuhan 430074, China

Full list of author information is available at the end of the article
}

environments affected organisms and their host sedimentary facies. This is particularly clear in shallow carbonate platform settings of the Peri-Tethys Ocean where Late Permian bioclastic limestones enriched in benthic fossils were replaced by microbialites in the Early Triassic (Kershaw et al. 1999, 2012; Lehrmann 1999; Ezaki et al. 2003; Lehrmann et al. 2003; Wang et al. 2005; Baud et al. 2007; Liu et al. 2007; Yang et al. 2006, 2011; Adachi et al. 2017; Deng et al. 2017; Fang et al. 2017; Tang et al. 2017; Pei et al. 2019).

Permian-Triassic boundary (PTB) microbialites exist in various forms, including stromatolites, thrombolites and dendrolites (Wang et al. 2019, and references therein). Most PTB microbialites are formed from calcified cyanobacteria, and also include miniaturized gastropods, ostracods and microconchids (Yang et al. 2011, 
2015a, 2015b; Wu et al. 2016) that point to the development of a relatively simple marine ecosystem of low diversity and tiering in the aftermath of the end-Permian extinction. South China is a key region for the study of PTB microbialites due to their abundance and vast distribution in the area. South China microbialites have mostly been described from the middle and upper Yangtze Platform (Zhu et al. 1994; Kershaw et al. 1999, 2002; Ezaki et al. 2003; Wang et al. 2005; Wu et al. 2006, 2007; Yang et al. 2006; Tang et al. 2017) and isolated platforms from the Nanpanjiang Basin (Lehrmann 1999; Yang et al. 1999; Lehrmann et al. 2003; Krull et al. 2004; Liu et al. 2007; Ezaki et al. 2008; Luo et al. 2011; Fang et al. 2017). In contrast, published occurrences of PTB microbialites from the lower Yangtze Platform are restricted to one example reported from Xishan of Jiangsu Province (Zheng et al. 2016). Recent study has shown that these microbialites have diverse structures that include stromatolites, tabular and domal thrombolites, and achieve quite variable thickness throughout the region (Wang et al. 2019), perhaps a function of the original topography of the seafloor and/or distance from land (Wang et al. 2019). Further data from sections in various palaeogeographic settings are required for an improved understanding of the geological background of PTB microbialites. We report a newly-discovered PTB microbialite from the Panjiazhuang section in Changxing, Zhejiang Province, $20 \mathrm{~km}$ to the east of the PTB Global Stratotype Section and Point (GSSP) at Meishan.

Globally, PTB microbialites are generally restricted to the Palaeo-Tethys region, apart from a Panthalassan example reported from Japan (Sano and Nakashima 1997).
Although the lower Yangtze Platform is commonly regarded as part of the Palaeo-Tethys, its eastern part was adjacent to Panthalassa. Our newly-described microbialites from the lower Yangtze Platform represent an unusual and important record of marine environments during the aftermath of the PTB biotic extinction in this transitional region. The Panjiazhuang locality is close to the relatively deep ramp facies GSSP of Meishan and thus provides a good opportunity for correlation of sedimentary and palaeoecological evolution between the various facies and successions preserved in the Lower Yangtze area.

\section{Geological setting and the Panjiazhuang succession}

Upper Permian strata in South China can be divided along palaeogeographic lines into: (1) deep-water siliceous-argillaceous facies that occur in a long and narrow region along the middle to lower modern Yangtze River; and (2) shallow water carbonate platform facies that dominate the southern part of this region (Fig. 1). The major regression at the end of the Permian resulted in the subaerial exposure and extensive erosion of shallow-water carbonate platforms (Yin et al. 2014). The succeeding transgression led to the widespread formation of microbialite across these partially eroded platforms. Several of these microbialites have been dated using conodonts, which suggest that the microbialites are a diachronous unit that formed between the end-Permian and the Early Triassic (Liu et al. 2007; Jiang et al. 2014; Wang et al. 2016). Newly explored sections including Xishan (Zheng et al. 2016), and
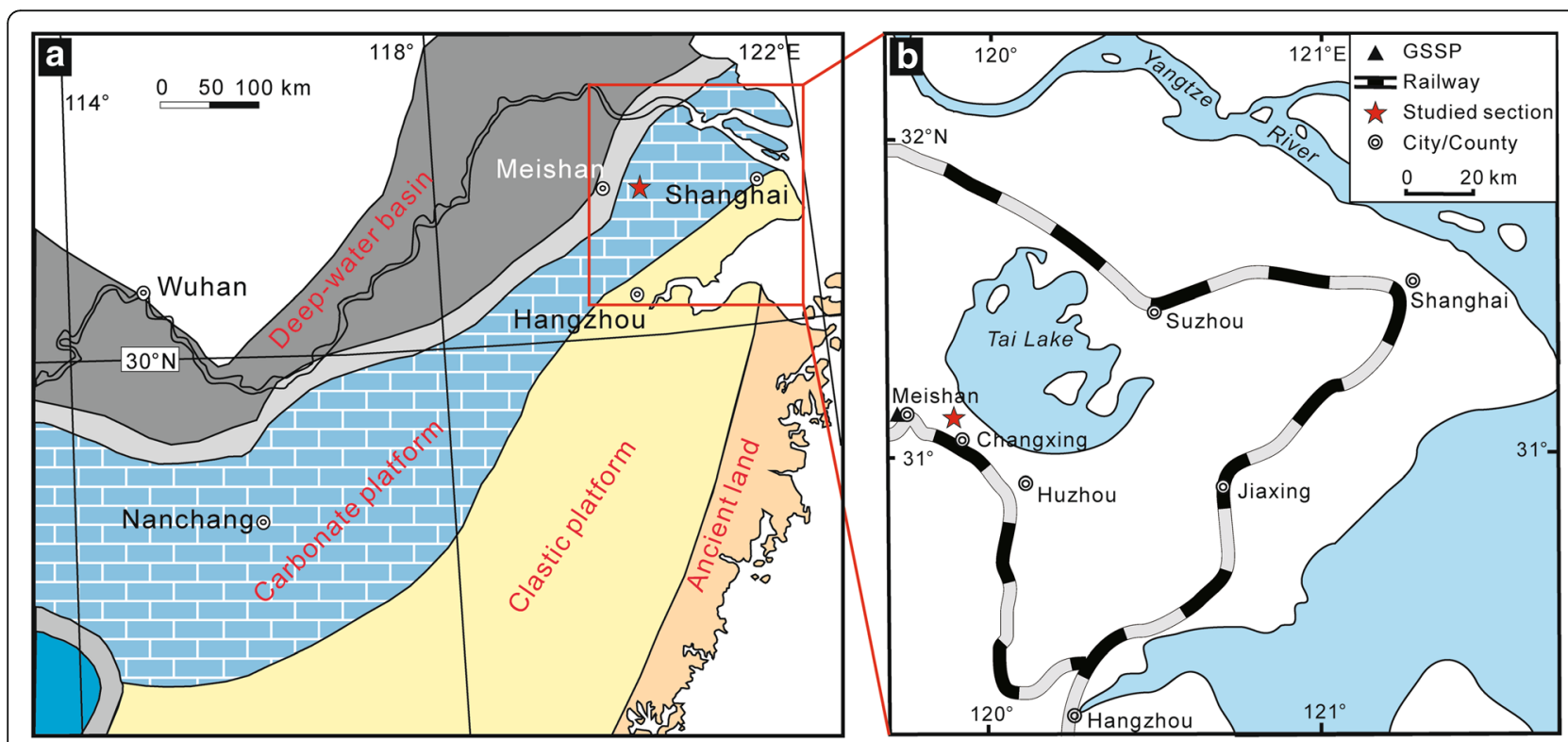

Fig. 1 a Late Permian palaeogeography of South China (modified from Feng et al. 1997); b Geographical location of the Panjiazhuang section. The location of the Panjiazhuang section $\left(31^{\circ} 02^{\prime} 40^{\prime \prime} \mathrm{N}, 119^{\circ} 51^{\prime} 35^{\prime \prime} \mathrm{E}\right)$ is marked by a red star 
Panjiazhuang, as well as data from Songshan (Wang et al. 1990), show that the distribution of platform carbonates in the Lower Yangtze area is larger than suggested by Feng et al. (1997). A modified palaeogeography based on that of Feng et al. (1997) is used in this study (Fig. 1).

The Permian-Triassic strata of the Lower Yangtze area have been the subject of concerted research effort, and include the well-known Meishan GSSP (Yin et al. 2001; Xie et al. 2005; Shen et al. 2011; Li et al. 2016). The Meishan section itself, has been considered to record sedimentation in a platform ramp setting during the end Permian due to the presence of turbidites in the succession (Li et al. 2016). However, detailed carbonate microfacies analysis has revealed that the influence of turbidity currents on deposition at Meishan section was negligible, and so a lower shelfal setting remains a possibility for Meishan section. Not far from Meishan section, the Huangzhishan section in southeastern Changxing County preserves abundant calcareous sponges, suggestive of the deposition on a carbonate platform (Chen et al. 2009b). However, the lack of microbialites at Huangzhishan section indicates that the water depth around the PTB interval was probably deeper than that of a typical shallow platform. In contrast, our newly studied Panjiazhuang section $\left(31^{\circ} 02^{\prime} 40^{\prime \prime} \mathrm{N}, 119^{\circ} 51^{\prime} 35^{\prime \prime} \mathrm{E}\right), 20 \mathrm{~km}$ east of the GSSP at Meishan, contains abundant Late Permian calcareous algae, typical for an upper marine shelf setting. Microbialites in the aftermath of the end-Permian extinction at Panjiazhuang section are comparable to those reported from other contemporaneous shallow carbonate platform settings in South China, but with some differences, described below.

Until recently, the age of the South China microbialites has not been fully understood. Early studies found the basal Triassic conodont Hindeodus parvus within the microbialite unit itself (Kershaw et al. 2002; Ezaki et al. 2003, 2008; Lehrmann et al. 2003; Yang et al. 2006; Chen et al. 2009a). Recently, this species has been found at the bottom of the microbialite unit in some sections (Liu et al. 2007; Jiang et al. 2014; Wang et al. 2016), indicating that microbialite formation, at least in some areas, started in the earliest Triassic rather than the latest Permian. Of course, even though Hindeodus parvus first appears within the microbialites in some sections, this does not necessarily mean that the PTB lies within those microbialites. Sampling bias and taphonomy, affect the placement of the PTB in these unusual deposits. If one considers the microbialites to be an anachronistic facies, their appearance in the sedimentary record can reasonably be assumed to represent the onset of particular marine conditions, and thus can be approximately thought as isochronous. At Panjiazhuang section, several samples from the PTB interval were processed for conodonts, but unfortunately, none has been found. Given that the first occurrence of Hindeodus parvus is at the base of the microbialite unit in some sections (Liu et al. 2007; Jiang et al. 2014; Wang et al. 2016), we consider that the PTB also lies at the base of the microbialites at Panjiazhuang section.

\section{Sedimentary succession at Panjiazhuang section}

The sedimentary succession at Panjiazhuang section begins with gray, thick-bedded limestones belonging to the Upper Permian Changxing Formation, of which only 3.4 $\mathrm{m}$ is exposed. The top of the Changxing Formation exhibits a distinctive purple-red weathering crust. Above this, more than three meters of microbialites are developed above the end-Permian mass extinction boundary (Fig. 2). The microbialites at Panjiazhuang section are typical thrombolites; no stromatolites or dendrites are seen. The microbialites are overlain by thin-bedded micritic limestones intercalated with oncolites and thin-bedded shelly clastic levels.

\subsection{Late Permian bioclastic limestone}

Study of thin sections from the Panjiazhuang section reveals that the Changxing Formation is mainly composed of bioclastic limestone cemented by sparry calcite (Fig. 3a), suggestive of a turbulent shallow-water platform environment. Abundant foraminifera (Fig. $3 \mathrm{~b}$ ) and calcareous algae (Fig. 3a) accumulated in the limestone. The dominant foraminiferal genera are Nodosinelloides, Ichthyofrondina, Geinitzina, Reichelina, Cribrogenerina, Globivalvulina, Palaeofusulina, whilst Gymnocodium, Permocalculus and Pseudovermiporella are the dominant calcareous algae. The presence of abundant calcareous algae indicates that the sea floor was within the euphotic zone. The

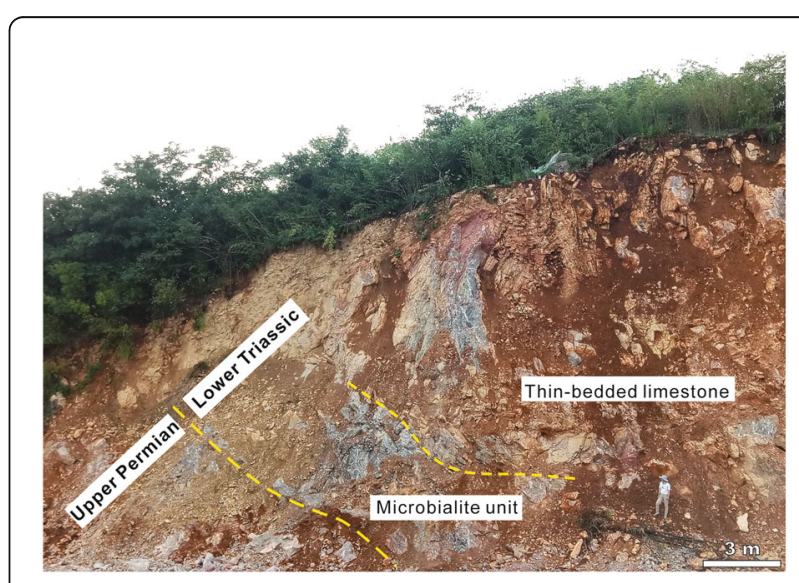

Fig. 2 Outcrop of the sedimentary sequence across the Permian-Triassic boundary in the Panjiazhuang section 
foraminiferal assemblage is similar to those from shallow water platforms elsewhere in South China where Reichelina, Cribrogenerina, Palaeofusulina are also commonly found (Yang et al. 2016). The distribution of foraminifera appears to be dependent on both water depth and substrate. Thus, the dominant taxa in Changhsingian limestones are usually Nodosaria and Glomospira, whilst Pachyphloia is more commonly found in contemporaneous siliceous mudstones, argillaceous siltstones and cherts ( $\mathrm{Gu}$ et al. 2002). It has been suggested that Globivalvulina, with its spherical test, possessed an ability to resist the force of water in turbulent environments (Zhang 2015). The occurrence of Globivalvulina before and after the end-Permian mass extinction (Song et al. 2007; Luo et al. 2013) indicates that it was a genus with strong adaptability.

\subsection{Early Triassic microbialites}

Early Triassic microbialites are developed above an obvious hiatal surface that tops the Late Permian bioclastic limestone and marks the end-Permian mass extinction level. The microbialites are placed within the Daye Formation and are separated from the underlying limestones by a crust of red iron oxide residue near the extinction boundary, which is probably a result of subaerial weathering following the end-Permian regression.
The microbialites at Panjiazhuang section attain a total thickness of $3.4 \mathrm{~m}$, and exhibit a typical thrombolitic structure with a micritic matrix surrounding sparry calcite clots (Fig. 4). The micritic matrix contains sparse ostracod shells and microconchid tubes, while the sparry calcite clots often contain well-preserved, hollow, spherical microbial fossils (Fig. 5). These fossils are generally interpreted as the remains of coccoidal microbes (Ezaki et al. 2003; Yang et al. 2011; Adachi et al. 2017). The diameter of a single coccoid is about $30-40 \mu \mathrm{m}$, and assemblages of several coccoid microfossils appear in clusters. Similar spherical microfossils were also reported from the Laolongdong section in Chongqing, where they were compared to the extant epiphytic cyanobacterium Stanieria (Wu et al. 2016).

The South China microbialites record the development of an unusual ecosystem dominated by microbes in the aftermath of the end-Permian mass extinction. That crisis wiped out many of those benthic organisms that adapted to normal, shallow marine environments, whilst some anoxia- or high-temperature-tolerant organisms survived and even flourished in the harsh conditions, spreading into newly available ecological niches. Like other reported Early Triassic microbialites (Jiang et al. 2010; Liu et al. 2010; Yang et al. 2011; Crasquin and Forel 2014; Wu et al. 2016), the metazoan fossils in this unit at Panjiazhuang section are dominated by ostracods, small gastropods and microconchid tubes (Fig. 6).

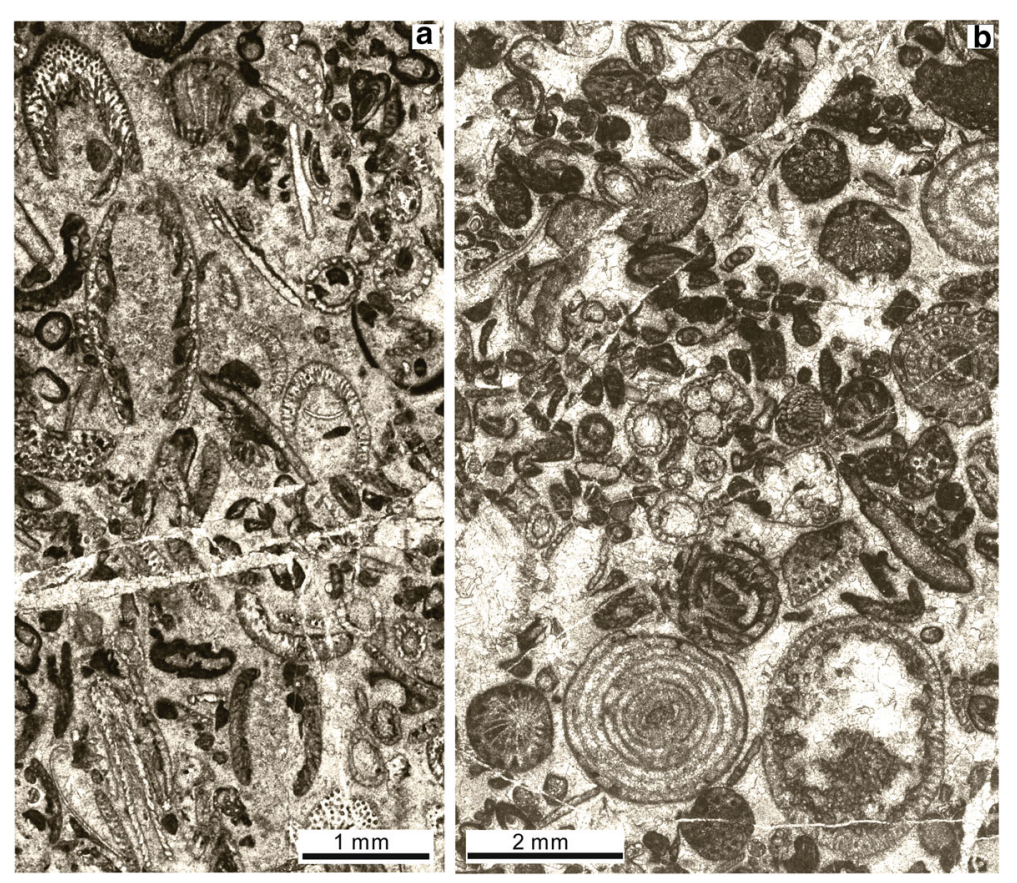

Fig. 3 a Calcareous algae (mainly Gymnocodium) and $\mathbf{b}$ foraminifera fossils preserved in the Late Permian bioclastic limestone in Panjiazhuang section (under plane-polarized light). The bioclastic limestone is grain-supported with sparry cement, indicating a turbulent, shallow marine depositional environment 

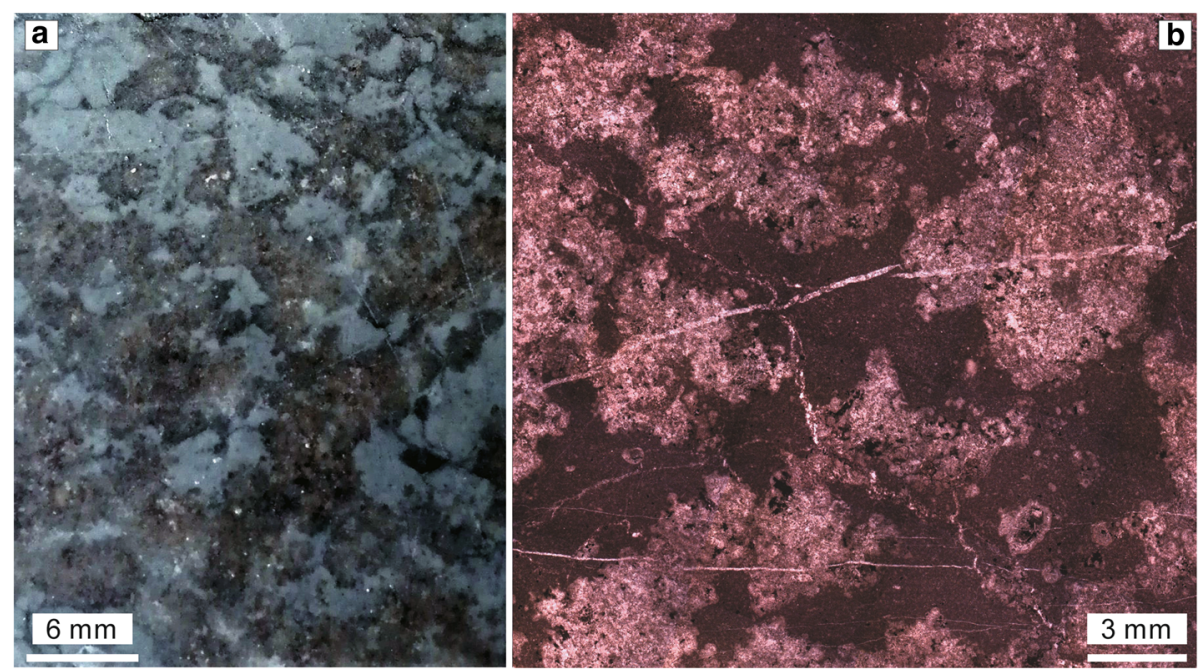

Fig. 4 Early Triassic thrombolite at Panjiazhuang section. a Polished section of thrombolite with light colored patches of micritic matrix and dark colored sparry calcite clots; $\mathbf{b}$ Thin section photomicrograph showing the thrombolitic fabric

\subsection{Micritic limestone with oncoids}

The Early Triassic microbialite unit at Panjiazhuang section is overlain by micrites that also contain oncoids and shell beds (Fig. $7 \mathrm{a}-\mathrm{c}$ ), all belonging to the Daye Formation. This unit records an increase in water depth and weakened hydrodynamics. It is noteworthy that thin-shelled bivalves occasionally appear within the micrite. These shells are typically deposited as broken fragments, suggesting that they are the product of event (e.g. storm) deposition. In contrast to the background deposits that have a micritic matrix, the shells within the shell beds are cemented by sparry calcite, consistent with periodic storm influence. Early Triassic storm sediments have been reported from many locations in South China

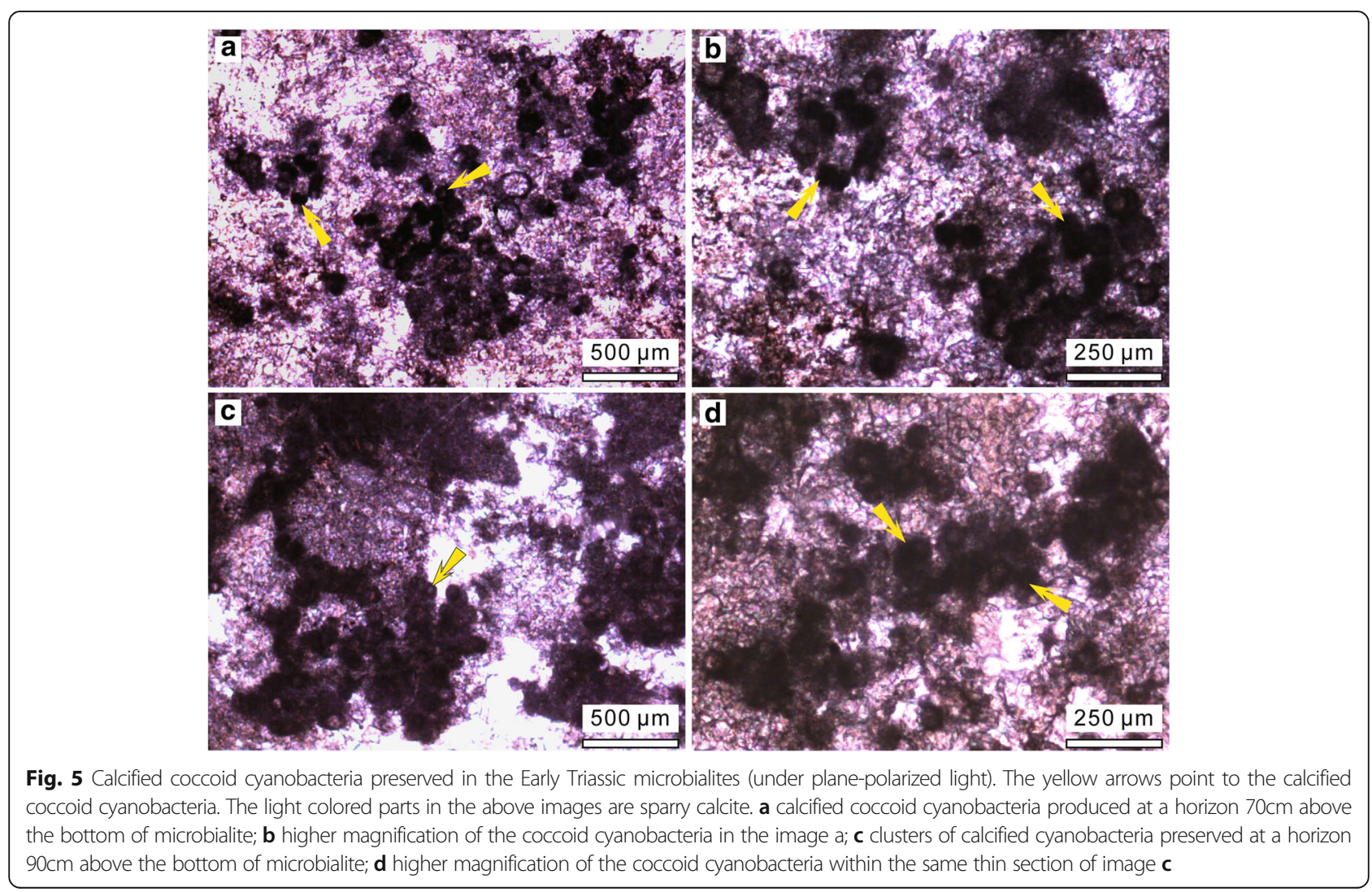



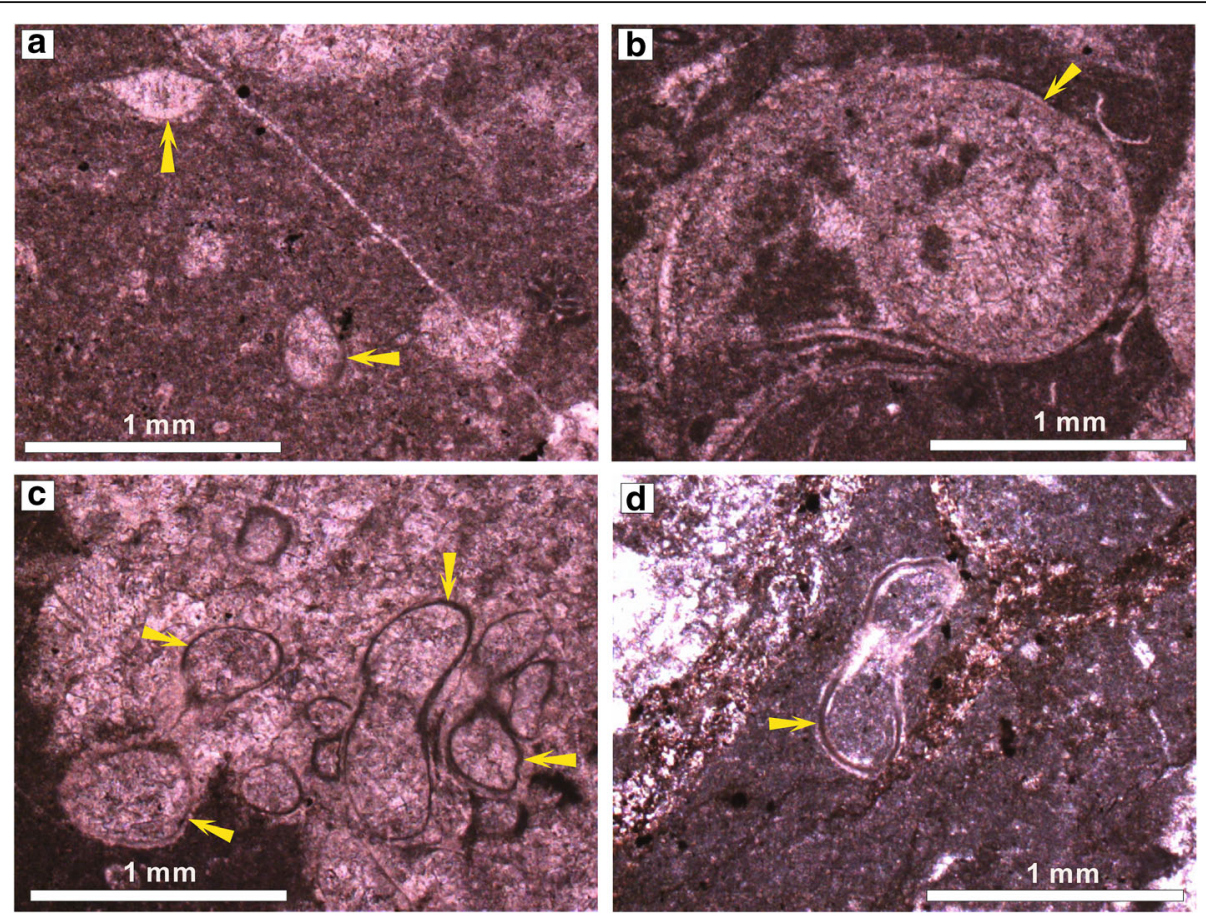

Fig. 6 Metazoan fossils in the Early Triassic microbialites at Panjiazhuang section. a Ostracods; b Gastropod; c and d Microconchid tubes
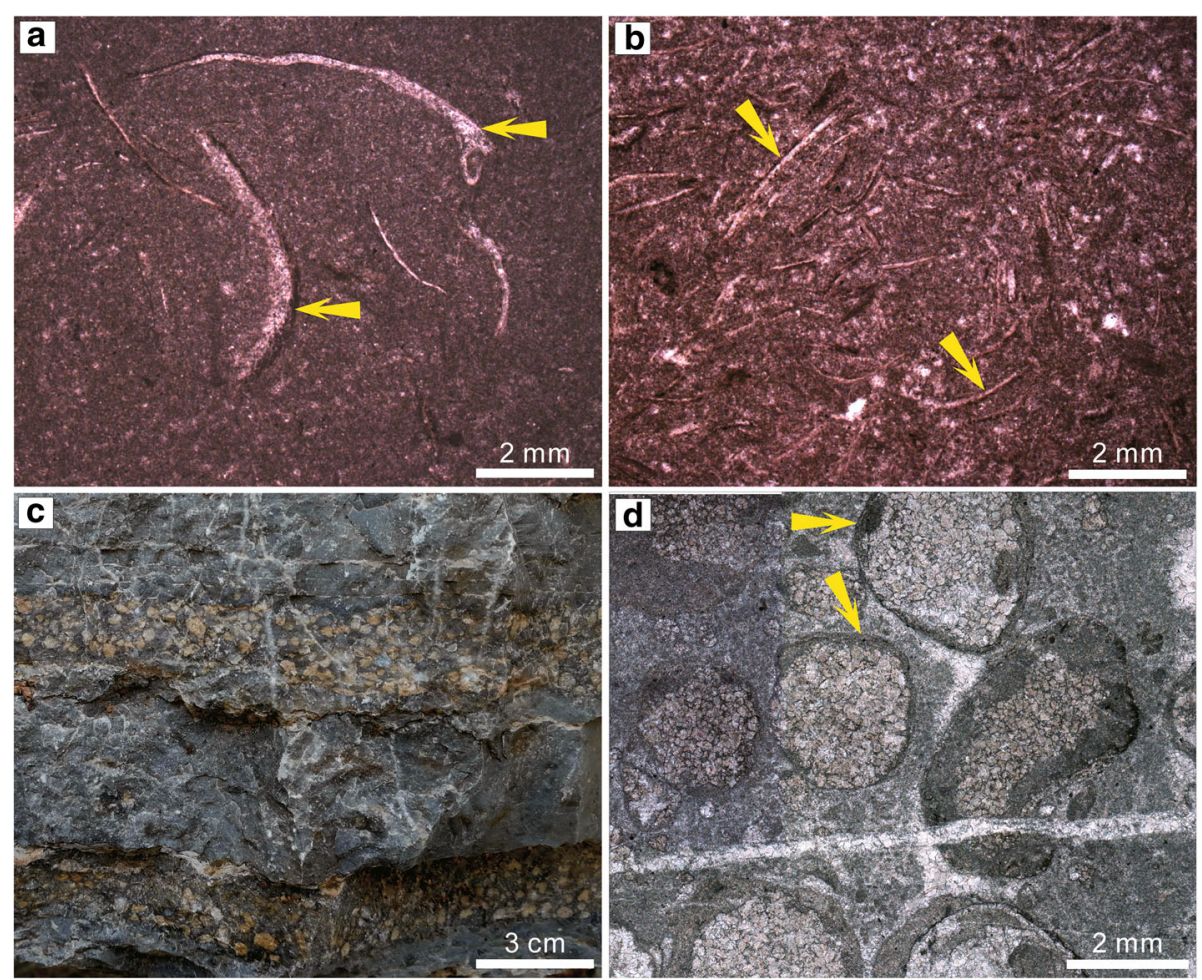

Fig. 7 Thin-bedded micritic limestone interbedded with oncoidal limestone. $\mathbf{a}$ and $\mathbf{b}$ Micritic limestone contains several thin-shelled fossil fragments marked with yellow arrows (under plane polarized light); c Field photo of the intercalated oncoidal limestone that we interpret to have been transported from a shallow platform setting; $\mathbf{d}$ Thin section photomicrograph of oncoids. The structure of most of these oncoids has clearly been destroyed during diagenesis with concentric laminae relics preserved only around some of the oncoids (marked with yellow arrows) 
(Zhang et al. 1987; Chen et al. 1991; Du et al. 1993), but most of these were found at much younger levels within the Triassic than the storm layers at Panjiazhuang section. The discovery of storm deposits from the top of the microbialite unit at Panjiazhuang section indicates that unusually stormy climatic conditions began much earlier than previously thought. Additionally, multiple oncoid beds are also seen within the micrite. The depositional environment of these oncoids would have been much shallower than the micrites (Deng et al. 2017) and we interpret their presence to be the result of storm flow transportation. Although these oncoids have a clear structure in outcrop, microscopic study shows that their internal structure has been almost completely destroyed by diagenetic processes. Relics of irregular concentric laminae can still be seen around some of the oncoids (Fig. 7d). The lack of a regular internal concentric structure within these oncoids may be due to their formation in shallow waters; their minerals are unstable in deep water environments and the dissolution of the original minerals in more offshore settings likely resulted in the disappearance of their concentric structure during the late stages of diagenesis.

\section{Redox conditions}

Pyrite framboid analysis is a useful proxy for ancient redox conditions. In modern environments, pyrite framboids form in the narrow iron-reduction zone developed at the redox boundary, but they cease growing in the more intensely anoxic conditions of the underlying sulfate-reduction zone (Wilkin et al. 1996; Wilkin and Barnes 1997; Suits and Wilkin 1998). If bottom waters become euxinic (i.e. free $\mathrm{H}_{2} \mathrm{~S}$ occurs within the water column), then framboids develop in the water column but are unable to achieve diameters much larger than $5 \mu \mathrm{m}$ before they sink below the iron reduction zone and cease to grow (Wilkin et al. 1996). Euxinic conditions are therefore characterized by populations of tiny framboids with a narrow size range, whereas dysoxic/weakly oxygenated seafloors produce framboid populations that are larger and more variable in size (Bond and Wignall 2010). Several recent studies have applied the pyrite framboid technique to PTB sequences (Bond and Wignall 2010; Liao et al. 2010, 2017; Li et al. 2016), highlighting the complexity of redox conditions during and after the end-Permian mass extinction. The method assumes that measured framboids are synsedimentary, and are not formed during diagenesis, although recent research indicates that the influence of diagenesis on pyrite framboid sizes is minimal (Huang et al. 2019). The presence of pyrite framboids in the PTB microbialites has been a topic of mixed interpretations. Some authors suggest that pyrite framboids in the PTB microbialites indicate deposition in shallow dysoxic waters(Liao et al. 2010, 2017), whereas others infer oxic conditions prevailed during the deposition of the microbialites on the basis of the increased abundance and size of metazoan fossils, together with the low total organic carbon (TOC) and total sulfur (TS) contents at the Yudongzi section in Sichuan Province (Tang et al. 2017). Using the modern Black Sea as a model, Kershaw (2015) suggested that pyrite framboids in the PTB microbialites may have originated below the redox boundary further offshore than the site of microbialite deposition before being transported onto the shelf during upwelling, where they became incorporated into oxygenated sediments. This would result in pyrite framboids providing a mixed signal for benthic redox conditions (Kershaw 2015).

In this study, we chose several samples from 12 horizons in the Panjiazhuang section, and analyzed the abundance and diameter of pyrite framboids. No pyrite framboids were observed in the bioclastic limestone of the Upper Permian Changxing Formation below the mass extinction boundary (MEB). Above the MEB, the lower part of the microbialite unit contains only crystalline pyrite, and pyrite framboids remain absent. Abundant pyrite framboids were found from the upper part of the microbialite unit and within the overlying thin-bedded micritic limestone (Fig. 8). There is no evidence that they were affected by diagenesis, and so we assume that they provide a realistic proxy for redox conditions.

The absence of pyrite in the Late Permian limestones indicates that well-oxygenated conditions prevailed prior to the end-Permian mass extinction. The lower part of the microbialite unit contains crystalline pyrite, but again the absence of pyrite framboids suggests that anoxia did not develop within the water column during the early stages of microbialite deposition. The occurrence of abundant pyrite framboids with mean diameters ranging from $7.83-14.18 \mu \mathrm{m}$ from the upper part of the microbialite unit (Figs. 9 and 10) suggests that dysoxic conditions developed, with framboids forming both within the water column and the sediment (Wilkin et al. 1996). Abundant framboids with mean diameter of $7.98 \mu \mathrm{m}$ were found in the thin-bedded micritic limestone overlying the microbialite, again suggestive of dysoxic conditions (Wignall and Newton 1998; Figs. 9 and 10). It is notable that the shelly and oncoidal interbeds within the micritic limestone do not contain framboids. It is interpreted to be the result of periodic storm deposition that briefly reoxygenated the sea floor.

\section{Discussion}

Sedimentary facies analysis of the Panjiazhuang section indicates that the deposition took place in a typical shallow carbonate platform environment between the Late Permian and the earliest Triassic. This contrasts with the nearby Meishan section, which comprises slope 

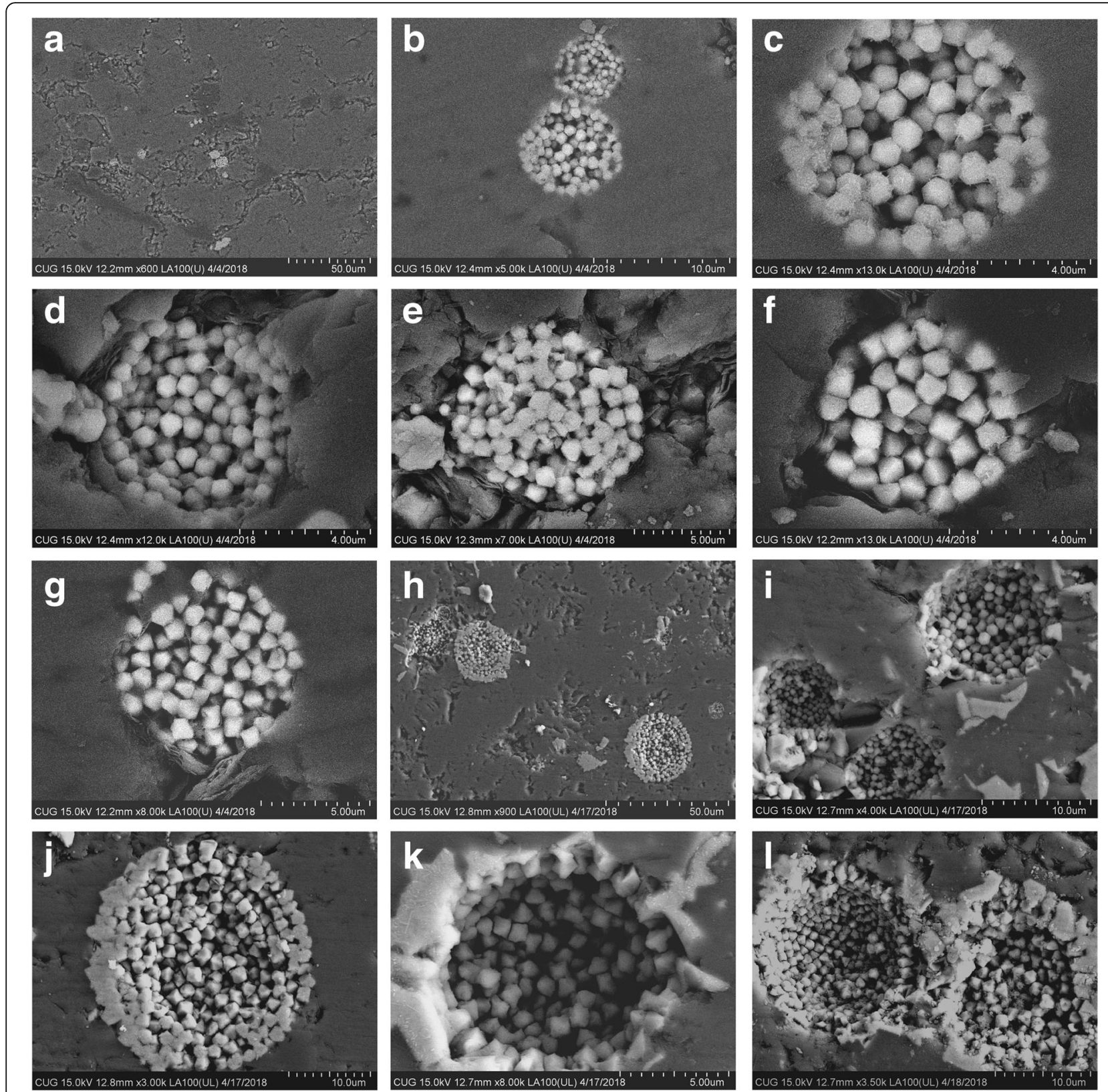

Fig. 8 Back-scattered electron microscope images of pyrite framboids from the Panjiazhuang section. a-g Pyrite framboids in thin-bedded micritic limestone of the Early Triassic; $\mathbf{h}$-I Pyrite framboids in the microbialite

facies from the platform margin (Feng et al. 1997). The nearby Huangzhishan section to the southeast of Changxing County was also considered to represent a shallow water platform environment (Chen et al. 2009b), but calcareous algae at Huangzhishan section are much less abundant than those at Panjiazhuang section, suggesting that the former records a somewhat more offshore setting than the Panjiazhuang section. Although these three sections are all very close to each other, the major differences in their sedimentary facies imply a complex palaeogeographic pattern and facies distribution in the Lower Yangtze region from the Late Permian to Early Triassic.

The thickness of the PTB microbialite unit varies across South China. This might be a function of the Early Triassic seas transgressing across more distal parts of the platform earlier than more proximal parts (i.e. of distance to the ancient land; Wang et al. 2019), as well as the original water depth. If the rate of tectonic subsidence in South China was relatively stable at that time, then the thickness of the microbialites is predicted to be relatively greater in areas of moderate water depth. The 

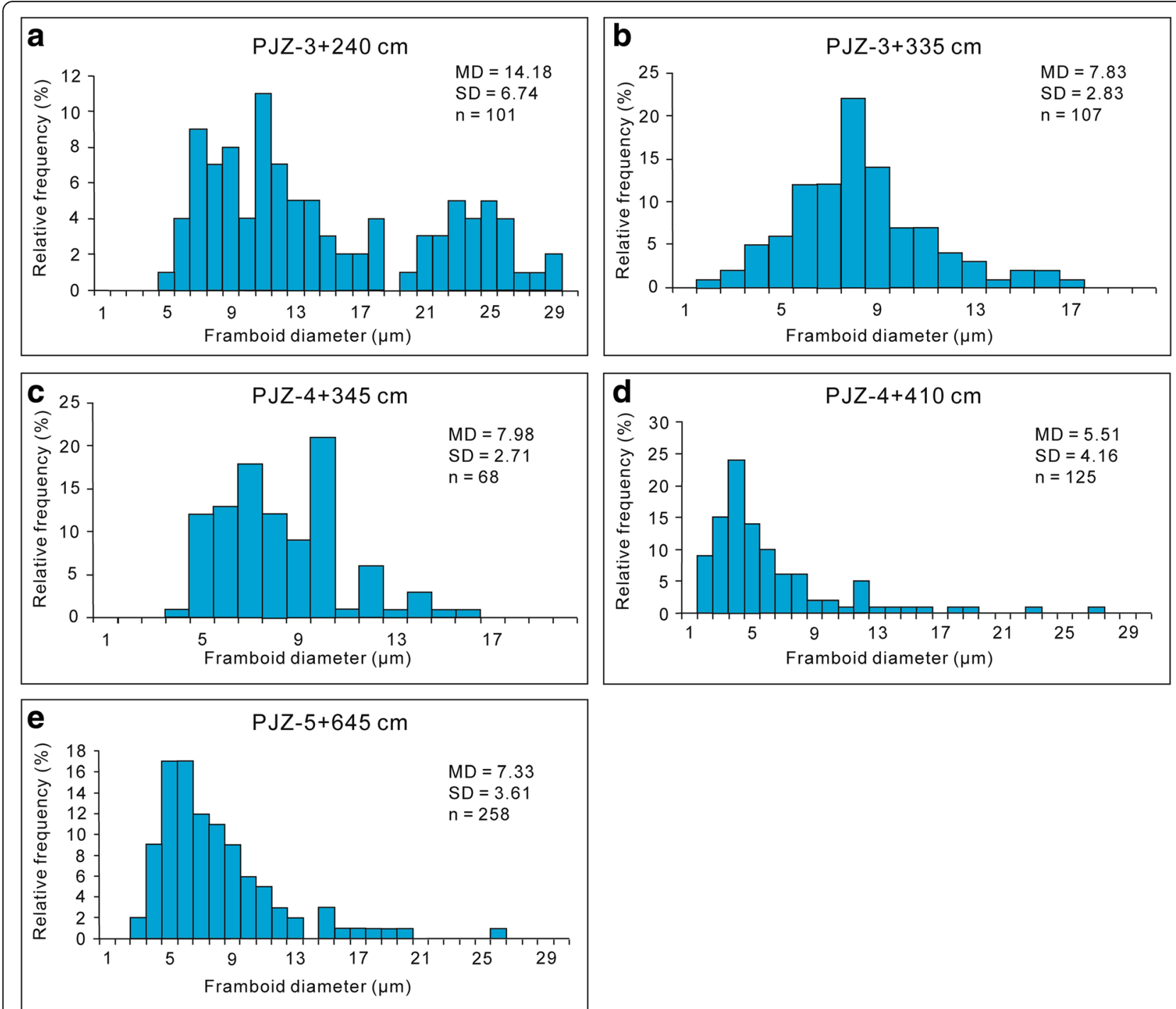

Fig. 9 Histograms showing the size-frequency distribution of pyrite framboids at Panjiazhuang section. MD=Mean diameter of the framboids $(\mu \mathrm{m}) ; \mathrm{SD}=$ Standard deviation of framboid diameters within a single population; $\mathrm{n}=$ Number of pyrite framboids measured in each sample. Each histogram corresponds to the samples marked from a to e in section column of Fig. 10, and each suggests the deposition under dysoxic conditions

microbialite unit at Panjiazhuang section only attains a thickness of $3.4 \mathrm{~m}$, which is relatively small compared to other manifestations, suggesting that the original water depth in this area may have been quite large. The formation of microbialites at Panjiazhuang section might have been terminated early in this relatively deep setting by the Early Triassic sea-level rise, since its growth depends on the photosynthesis of cyanobacteria. Microbialites would have continued to grow in shallower water settings. There is clear evidence for this sea-level rise at Panjiazhuang section. Thus, within the microbialite unit, in addition to the cyanobacteria, benthic organisms consist of small gastropods, microconchid tubes and ostracod fossils. Towards the top of the microbialite unit, thin-shelled fossils appear, and these dominate the fauna in the overlying thin-bedded micritic limestone, indicating that rapid sea-level rise terminated the formation of microbialites. Some of these shell fragments are cemented by sparry calcite, suggesting that the deeper water environment was periodically agitated by turbulent hydrodynamic activity. Storm deposition was likely responsible for the formation of shell beds in the micritic sediments because many of the long axes of the shells are near-perpendicular to bedding. Ultimately, it seems that rapid transgression and sea-level rise was responsible for the termination of microbialite formation in this region.

The increase in water depth during the Early Triassic transgression had implications for benthic oxygen levels. 


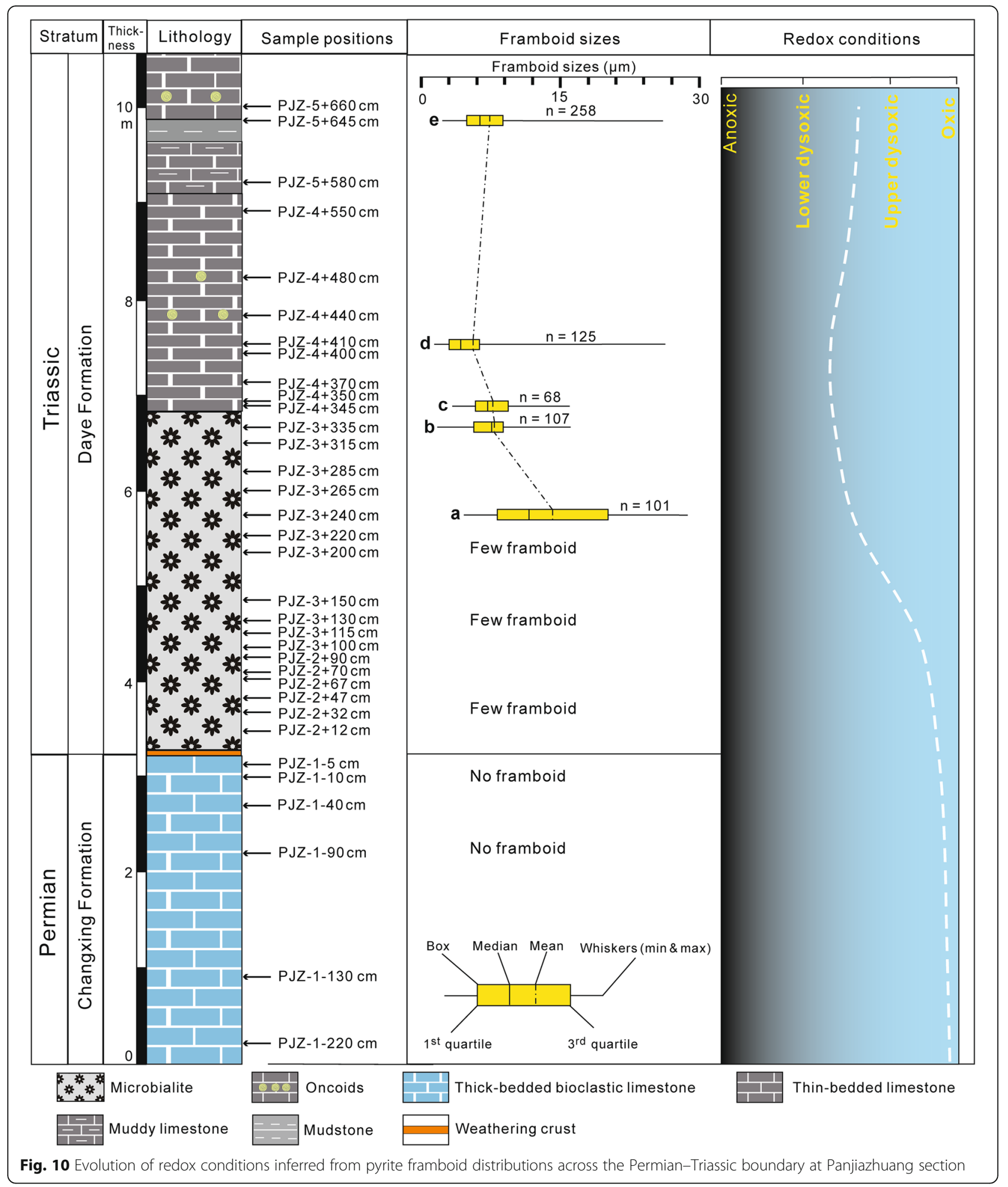

At Panjiazhuang section, the rapid deepening led to a decrease in oxygenation levels, as suggested by the appearance of abundant small pyrite framboids from the top of the microbialite and in the overlying micritic limestone. Previous studies have found abundant pyrite framboid populations from the lower parts of some PTB microbialites, suggesting that they formed under dysoxic conditions (Liao et al. 2010, 2017). In contrast, the lower part of the microbialite at Panjiazhuang section does not contain pyrite framboids. The reason for these 
discrepancies is unclear, but the heterogeneity of marine chemistry may be a compounding factor. The formation of pyrite framboids requires not only hydrogen sulfide but also ferrous ions in the water column. An insufficient supply of these materials from the seawater is a possible reason for the absence of pyrite framboids in the lower microbialite unit at Panjiazhuang section.

Previous studies have shown that calcified cyanobacteria tend to record very shallow water environments, whilst deeper water settings are not conducive to cyanobacterial calcification. Surprisingly, the microbialite in this section is rich in calcified cyanobacteria and the reason for this is unclear. It is possible that the palaeogeographic setting of this section resulted in it being more easily affected by the upwelling of the deep alkaline seawater due to its close proximity to the Panthalassan Ocean.

\section{Conclusions}

The microbialite unit observed at Panjiazhuang section in Changxing County, Zhejiang Province, South China formed on a shallow water carbonate platform in the aftermath of the end-Permian mass extinction. Abundant calcified cyanobacteria fossils and small gastropods, microconchid tubes and ostracods are the main components of this fossil community.

Thrombolite is the only type of microbialite in the study section, indicating the microbialite formed at slightly deeper water depths than the PTB stromatolites seen elsewhere in South China.

The occurrence of micritic limestones above the microbialite records a rapid deepening during the Early Triassic transgression. Rising sea levels caused a concomitant decrease in benthic oxygen levels and the formation of abundant small pyrite framboids. This deepening and decline in oxygen levels is interpreted to have terminated the formation of microbialites in this region.

Calcified cyanobacteria in the thrombolites at Panjiazhuang section are much more common than in other PTB microbialites in South China. We assume this is a function of proximity to the adjacent Panthalassan Ocean, which could have supplied alkaline deep waters to the region during upwelling. This water would have facilitated the calcification of cyanobacteria at Panjiazhuang section.

\section{Abbreviations}

GSSP: Global Stratotype Section and Point; MEB: Mass extinction boundary: PTB: Permian-Triassic boundary; TOC: Total organic carbon; TS: Total sulfur

\section{Acknowledgements}

We thank Professor Zeng-Zhao Feng for his helpful suggestions on an early manuscript, and two anonymous reviewers for their valuable comments and constructive suggestions which significantly improved the manuscript. This study was jointly supported by the National Natural Science Foundation of China (Grants No. 41730320 and No. 41572001) and the 111 project (B08030).

\section{Availability of data and materials}

The datasets and material analyzed in this study are available from the corresponding author upon reasonable request.

\section{Authors' contributions}

YFH, YBW, TW, ZXY, JYJ and YQS conducted the field work and collected the samples. YFH made a microscopic observation and photograph of the sheets. YFH and AHY identified and analyzed the multicellular fossils in the microbialites. YFH and YBW drafted the manuscript, and organized and revised the drawings. DPGB made a detailed explanation of the principle of pyrite framboid as an indicator for ancient redox conditions and did a modification of the English language of this paper. All authors read and approved the final manuscript.

\section{Competing interests}

The authors declare that they have no competing interests. All authors have approved this manuscript and no author has financial or other contractual agreements that might cause conflicts of interest.

\section{Publisher's Note}

Springer Nature remains neutral with regard to jurisdictional claims in published maps and institutional affiliations.

\section{Author details}

${ }^{1}$ State Key Laboratory of Geological Processes and Mineral Resources, School of Earth Sciences, China University of Geosciences (Wuhan), Wuhan 430074, China. ${ }^{2}$ Department of Geography, Geology and Environment, University of Hull, Hull HU6 7RX, UK.

Received: 5 December 2018 Accepted: 7 May 2019

Published online: 30 May 2019

\section{References}

Adachi, N., Y. Asada, Y. Ezaki, and J.B. Liu. 2017. Stromatolites near the Permian-Triassic boundary in Chongyang, Hubei Province, South China: A geobiological window into palaeo-oceanic fluctuations following the endPermian extinction. Palaeogeography, Palaeoclimatology, Palaeoecology 475: 55-69.

Baud, A., S. Richoz, and S. Pruss. 2007. The lower Triassic anachronistic carbonate facies in space and time. Global and Planetary Change 55 (1-3): 81-89.

Benton, M.J., and A.J. Newell. 2014. Impacts of global warming on PermoTriassic terrestrial ecosystems. Gondwana Research 25 (4): 1308-1337.

Bond, D.P.G., and P.B. Wignall. 2010. Pyrite framboid study of marine Permian-Triassic boundary sections: A complex anoxic event and its relationship to contemporaneous mass extinction. GSA Bulletin 122 (7-8): 1265-1279.

Chen, J., T.W. Beatty, C.M. Henderson, and H. Rowe. 2009. Conodont biostratigraphy across the Permian-Triassic boundary at the Dawen section, great Bank of Guizhou, Guizhou Province, South China: Implications for the late Permian extinction and correlation with Meishan. Journal of Asian Earth Sciences 36 (6): 442-458.

Chen, L.Z., X.M. Luo, and J.D. Xiao. 1991. Early Triassic calcareous storm deposits in southeastern Hubei. Sedimentary Facies and Palaeogeography 11 (3): 1-9 (in Chinese with English abstract).

Chen, Z.Q., and M.J. Benton. 2012. The timing and pattern of biotic recovery following the end-Permian mass extinction. Nature Geoscience 5 (6): 375-383.

Chen, Z.Q., J. Tong, K. Zhang, H. Yang, Z. Liao, H. Song, and J. Chen. 2009b. Environmental and biotic turnover across the Permian-Triassic boundary on a shallow carbonate platform in western Zhejiang, South China. Australian Journal of Earth Sciences 56 (6): 775-797.

Crasquin, S., and M.-B. Forel. 2014. Ostracods (Crustacea) through PermianTriassic events. Earth-Science Reviews 137: 52-64. 
Deng, B.Z., Y.B. Wang, A. Woods, S. Li, G.S. Li, and W.H. Chen. 2017. Evidence for rapid precipitation of calcium carbonate in South China at the beginning of early Triassic. Palaeogeography, Palaeoclimatology, Palaeoecology 474: 187-197.

Du, Y.S., L.Z. Chen, and Y.Q. Dong. 1993. Middle and late early Triassic sedimentary facies and palaeogeography in southeastern Hubei. Sedimentary Facies and Palaeogeography 13 (4): 19-27 (in Chinese with English abstract).

Ezaki, Y., J.B. Liu, and N. Adachi. 2003. Earliest Triassic microbialite micro- to megastructures in the Huaying area of Sichuan Province, South China: Implications for the nature of oceanic conditions after the end-Permian extinction. Palaios 18 (4-5): 388-402.

Ezaki, Y., J.B. Liu, T. Nagano, and N. Adachi. 2008. Geobiological aspects of the earliest Triassic microbialites along the southern periphery of the tropical Yangtze platform: Initiation and cessation of a microbial regime. Palaios 23 (6): 356-369.

Fang, Y.H., Z.Q. Chen, S. Kershaw, H. Yang, and M. Luo. 2017. PermianTriassic boundary microbialites at Zuodeng section, Guangxi Province, South China: Geobiology and palaeoceanographic implications. Global and Planetary Change 152: 115-128.

Farabegoli, E., and M.C. Perri. 2012. Millennial physical events and the endPermian mass mortality in the western Palaeotethys: Timing and primary causes. In Earth and life, ed. J.A. Talent, 719-758. Dordrecht: Springer.

Feng, Z.Z., Z.D. Bao, S.H. Wu, Y.T. Li, and G.L. Wang. 1997. Lithofacies palaeogeography of the early and middle Triassic of South China. Scientia Geologica Sinica 32 (2): 212-220.

Gu, S.Z., J.C. Pei, F.Q. Yang, and Y.Q. Gao. 2002. Smaller foraminifera Fauna from the Changxingian of the Sidazhai section, Ziyun county, southern Guizhou Province. Acta Micropalaeontologica Sinica 19 (2): 163-169.

Hallam, A., and P.B. Wignall. 1999. Mass extinctions and sea-level changes. Earth-Science Reviews 48 (4): 217-250.

Heydari, E., J. Hassanzadeh, W.J. Wade, and A.M. Ghazi. 2003. Permian-Triassic boundary interval in the Abadeh section of Iran with implications for mass extinction: Part 1 - Sedimentology. Palaeogeography, Palaeoclimatology, Palaeoecology 193 (3-4): 405-423.

Hochuli, P.A., E. Schneebeli-Hermann, G. Mangerud, and H. Bucher. 2017. Evidence for atmospheric pollution across the Permian-Triassic transition. Geology 45 (12): 1123-1126.

Huang, Y.G., Z.Q. Chen, T.J. Algeo, L.S. Zhao, A. Baud, G.M. Bhat, L. Zhang, and Z. Guo. 2019. Two-stage marine anoxia and biotic response during the Permian-Triassic transition in Kashmir, northern India: Pyrite framboid evidence. Global and Planetary Change 172: 124-139.

Jiang, H.S., X.L. Lai, Y.D. Sun, P.B. Wignall, J.B. Liu, and C.B. Yan. 2014. Permian-Triassic conodonts from Dajiang (Guizhou, South China) and their implication for the age of microbialite deposition in the aftermath of the end-Permian mass extinction. Journal of Earth Science 25 (3): 413-430.

Jiang, H.X., Y.S. Wu, J.B. Diao, and J.Y. Chen. 2010. A dwarf Euomphalid fauna from the Permian-Triassic boundary in Laolongdong, Beibei, Chongqing: Opportunity taxa surviving the disaster event? Acto Geoscientica Sinica 31 (2): 163-169 (in Chinese with English abstract).

Kershaw, S. 2015. Modern Black Sea oceanography applied to the endPermian extinction event. Journal of Palaeogeography 4 (1): 52-62.

Kershaw, S., S. Crasquin, Y. Li, P.Y. Collin, M.B. Forel, X.N. Mu, A. Baud, Y. Wang, S. Xie, F. Maurer, and L. Guo. 2012. Microbialites and global environmental change across the Permian-Triassic boundary: A synthesis. Geobiology 10 (1): 25-47.

Kershaw, S., L. Guo, A. Swift, and J.S. Fan. 2002. ?Microbialites in the Permian-Triassic boundary interval in Central China: Structure, age and distribution. Facies 47 (1): 83-89.

Kershaw, S., T.S. Zhang, and G.Z. Lan. 1999. A ?Microbialite carbonate crust at the Permian-Triassic boundary in South China, and its palaeoenvironmental significance. Palaeogeography Palaeoclimatology Palaeoecology 146: 1-18.

Krull, E.S., D.J. Lehrmann, D. Druke, B. Kessel, Y.Y. Yu, and R.X. Li. 2004. Stable carbon isotope stratigraphy across the Permian-Triassic boundary in shallow marine carbonate platforms, Nanpanjiang Basin, South China. Palaeogeography Palaeoclimatology Palaeoecology 204 (3-4): 297-315.
Lehrmann, D.J. 1999. Early Triassic calcimicrobial mounds and biostromes of the Nanpanjiang Basin, South China. Geology 27 (4): 359-362.

Lehrmann, D.J., J.L. Payne, S.V. Felix, P.M. Dillett, H.M. Wang, Y.Y. Yu, and J.Y. Wei. 2003. Permian-Triassic boundary sections from shallow-marine carbonate platforms of the Nanpanjiang Basin, South China: Implications for oceanic conditions associated with the end-Permian extinction and its aftermath. Palaios 18 (2): 138-152.

Li, G.S., Y.B. Wang, G.R. Shi, W. Liao, and L.X. Yu. 2016. Fluctuations of redox conditions across the Permian-Triassic boundary - New evidence from the GSSP section in Meishan of South China. Palaeogeography Palaeoclimatology Palaeoecology 448: 48-58.

Liao, W., D.P.G. Bond, Y.B. Wang, L. He, H. Yang, Z.T. Weng, and G.S. Li. 2017. An extensive anoxic event in the Triassic of the South China block: A pyrite framboid study from Dajiang and its implications for the cause(s) of oxygen depletion. Palaeogeography Palaeoclimatology Palaeoecology 486: 86-95.

Liao, W., Y.B. Wang, S. Kershaw, Z.T. Weng, and H. Yang. 2010. Shallowmarine dysoxia across the Permian-Triassic boundary: Evidence from pyrite framboids in the microbialite in South China. Sedimentary Geology 232 (1-2): 77-83.

Liu, H., Y.B. Wang, A.H. Yuan, H. Yang, H.J. Song, and S.X. Zhang. 2010. Ostracod fauna across the Permian-Triassic boundary at Chongyang, Hubei Province, and its implication for the process of the mass extinction. Science China Earth Sciences 53 (6): 810-817.

Liu, J.B., Y. Ezaki, S.R. Yang, H.F. Wang, and N. Adachi. 2007. Age and sedimentology of microbialites after the end-Permian mass extinction in Luodian, Guizhou Province. Journal of Palaeogeography 9 (5): 473-486 (in Chinese with English abstract).

Luo, G.M., Y.B. Wang, H. Yang, T.J. Algeo, L.R. Kump, J.H. Huang, and S.C. Xie 2011. Stepwise and large-magnitude negative shift in $\delta^{13} C_{\text {carb }}$ preceded the main marine mass extinction of the Permian-Triassic crisis interval. Palaeogeography Palaeoclimatology Palaeoecology 299 (1-2): 70-82.

Luo, H., Z.C. Zhou, H.W. Cai, Y.H. Zhu, Z.H. Wang, J.H. Chen, B. Xu, H. Yang, H.H. Chen, and D.S. Chen. 2013. Permian-Triassic boundary biostratigraphy and sedimentology at the Yudongzi section of Jiangyou, Sichuan Province. Journal of Stratigraphy 37 (1): 81-92 (in Chinese with English abstract).

Newell, N.D. 1967. Revolutions in the history of life. GSA Special Papers 89: 63-91.

Payne, J.L., and M.E. Clapham. 2012. End-Permian mass extinction in the oceans: An ancient analog for the twenty-first century? Annual Review of Earth and Planetary Sciences 40: 89-111.

Pei, Y., Z.Q. Chen, Y.H. Fang, S. Kershaw, S.Q. Wu, and M. Luo. 2019. Volcanism, redox conditions, and microbialite growth linked with the end-Permian mass extinction: Evidence from the Xiajiacao section (western Hubei Province), South China. Palaeogeography Palaeoclimatology Palaeoecology 519: 194-208.

Sano, H., and K. Nakashima. 1997. Lowermost Triassic (Griesbachian) microbial bindstone-cementstone facies, Southwest Japan. Facies 36 (1): 1-24.

Shen, Y.A., J. Farquhar, H. Zhang, A. Masterson, T.G. Zhang, and B.A. Wing. 2011. Multiple S-isotopic evidence for episodic shoaling of anoxic water during late Permian mass extinction. Nature Communications 2: 210-214.

Song, H.J., J.N. Tong, K.X. Zhang, Q.X. Wang, and Z.Q. Chen. 2007. Foraminiferal survivors from the Permian-Triassic mass extinction in the Meishan section, South China. Palaeoworld 16 (1-3): 105-119.

Song, H.J., P.B. Wignall, J.N. Tong, and H.F. Yin. 2013. Two pulses of extinction during the Permian-Triassic crisis. Nature Geoscience 6 (1): 52-56.

Suits, N.S., and R.T. Wilkin. 1998. Pyrite formation in the water column and sediments of a meromictic lake. Geology 26 (12): 1099-1102.

Tang, H., S. Kershaw, H. Liu, X.C. Tan, F. Li, G. Hu, C. Huang, L.C. Wang, C.B. Lian, L. Li, and X.F. Yang. 2017. Permian-Triassic boundary microbialites (PTBMs) in Southwest China: Implications for paleoenvironment reconstruction. Facies 63 (1): 2. https://doi.org/10.1007/s10347-016-0482-8.

Wang, L.N., P.B. Wignall, Y.B. Wang, H.S. Jiang, Y.D. Sun, G.S. Li, J.L. Yuan, and X L. Lai. 2016. Depositional conditions and revised age of the Permo-Triassic microbialites at Gaohua section, Cili County (Hunan Province, South China). Palaeogeography Palaeoclimatology Palaeoecology 443: 156-166.

Wang, S.Y., H.F. Zhu, Y.Z. Chen, and W.J. Shi. 1990. Distributive regularities of sedimentary facies during Changxing period of the late Permian in SuZhe-wan (Jiangsu-Zhejiang-Anhui provinces) adjacent area. 
Experimental Petroleum Geology 12 (3): 297-306 (in Chinese with English abstract).

Wang, T., R.V. Burne, A.H. Yuan, Y.B. Wang, and Z.X. Yi. 2019. The evolution of microbialite forms during the early Triassic transgression: A case study in Chongyang of Hubei Province, South China. Palaeogeography Palaeoclimatology Palaeoecology 519: 209-220.

Wang, Y.B., J.N. Tong, J.S. Wang, and X.G. Zhou. 2005. Calcimicrobialite after end-Permian mass extinction in South China and its palaeoenvironmental significance. Chinese Science Bulletin 50 (7): 665-671.

Wignall, P.B., and R. Newton. 1998. Pyrite framboid diameter as a measure of oxygen deficiency in ancient mudrocks. American Journal of Science 298 (7): 537-552.

Wilkin, R.T., and H.L. Barnes. 1997. Formation processes of framboidal pyrite. Geochimica et Cosmochimica Acta 61 (2): 323-339.

Wilkin, R.T., H.L. Barnes, and S.L. Brantley. 1996. The size distribution of framboidal pyrite in modern sediments: An indicator of redox conditions. Geochimica et Cosmochimica Acta 60 (20): 3897-3912.

Wu, Y.S., H.X. Jiang, and J.S. Fan. 2010. Evidence for sea-level falls in the Permian-Triassic transition in the Ziyun area, South China. Geological Journal 45 (2-3): 170-185.

Wu, Y.S., H.X. Jiang, W. Yang, and J.S. Fan. 2007. Microbialite of anoxic condition from Permian-Triassic transition in Guizhou, China. Science in China Series D: Earth Sciences 50 (7): 1040-1051.

Wu, Y.S., W. Yang, H.X. Jiang, and J.S. Fan. 2006. Petrologic evidence for sealevel drop in latest Permian in Jiangxi province, China and its meanings for the mass extinction. Acta Petrologica Sinica 22 (12): 3039-3046 (in Chinese with English abstract).

Wu, Y.S., G.L. Yu, H.X. Jiang, L.J. Liu, and R. Zhao. 2016. Role and lifestyle of calcified cyanobacteria (Stanieria) in Permian-Triassic boundary microbialites. Palaeogeography Palaeoclimatology Palaeoecology 448: 39-47.

Xie, S.C., R.D. Pancost, H.F. Yin, H.M. Wang, and R.P. Evershed. 2005. Two episodes of microbial change coupled with Permo/Triassic faunal mass extinction. Nature 434 (7032): 494-497.

Yang, H., Z.Q. Chen, and W.Q. Ou. 2015a. Microconchids from microbialites near the Permian-Triassic boundary in the Zuodeng section, Baise area, Guangxi Zhuang autonomous region, South China and their paleoenvironmental implications. Journal of Earth Science 26 (2): 157-165.

Yang, H., Z.Q. Chen, Y.B. Wang, W.Q. Ou, W. Liao, and X. Mei. 2015b. Palaeoecology of microconchids from microbialites near the PermianTriassic boundary in South China. Lethaia 48 (4): 497-508.

Yang, H., Z.Q. Chen, Y.B. Wang, J.N. Tong, H.J. Song, and J. Chen. 2011. Composition and structure of microbialite ecosystems following the end-Permian mass extinction in South China. Palaeogeography Palaeoclimatology Palaeoecology 308 (1-2): 111-128.

Yang, H., S.X. Zhang, H.S. Jiang, and Y.B. Wang. 2006. Age and general characteristics of the calcimicrobialite near the Permian-Triassic boundary in Chongyang, Hubei Province. Journal of China University of Geosciences 17 (2): 121-125, 131

Yang, L.R., H.J. Song, J.N. Tong, D.L. Chu, L. Liang, K. Wu, and L. Tian. 2016. The extinction pattern of foraminifers during the Permian-Triassic crisis at the Maochang section, Ziyun, Guizhou Province, South China. Acta Micropalaeontologica Sinica 33 (3): 229-250.

Yang, S.R., W.C. Hao, and X.P. Wang. 1999. Conodont evolutionary lineages, zonation and P-T boundary beds in Guangxi, China. In Biotic and geological developments in the Palaeo-Tethys in China, ed. A. Yao, Y. Ezaki, W.C. Hao, and X.P. Wang, 81-95. Beijing: Peking University Press (in Chinese).

Yin, H.F., H.S. Jiang, W.C. Xia, Q.L. Feng, N. Zhang, and J. Shen. 2014. The end-Permian regression in South China and its implication on mass extinction. Earth-Science Reviews 137 (Supplement C): 19-33.

Yin, H.F., S.C. Xie, G.M. Luo, T.J. Algeo, and K.X. Zhang. 2012. Two episodes of environmental change at the Permian-Triassic boundary of the GSSP section Meishan. Earth-Science Reviews 115 (3): 163-172.

Yin, H.F., K.X. Zhang, J.N. Tong, Z.Y. Yang, and S.B. Wu. 2001. The global stratotype section and point (GSSP) of the Permian-Triassic boundary. Episodes 24 (2): 102-114.

Zhang, G.D., J.C. Zhu, F.K. Chou, Y.Y. Wang, and J.Z. Zheng. 1987. Sedimentary characteristics of early Triassic carbonate storm and clastic flows at the low Yangtze area. Marine Geology and Quaternary Geology 7 (2): 99-109 (in Chinese with English abstract).

Zhang, M.H. 2015. Late Permian Deep Water Foraminiferal Fauna from South China, PhD thesis. Wuhan: China University of Geosciences (in Chinese with English abstract).

Zheng, Q.F., C.Q. Cao, Y. Wang, H. Zhang, and Y. Ding. 2016. Microbialite concretions in a dolostone crust at the Permian-Triassic boundary of the Xishan section in Jiangsu Province, South China. Palaeoworld 25 (2): 188-198.

Zhu, X.S., C.Y. Wang, H. Lü, X.N. Mu, L.X. Zhang, Z.S. Qin, H. Luo, W.R. Yang, and Z.Q. Deng. 1994. Permian-Triassic boundaries in Jiangxi, China. Acta Micropalaeontologica Sinica 11 (4): 439-452 (in Chinese with English abstract).

\section{Submit your manuscript to a SpringerOpen ${ }^{\circ}$ journal and benefit from:}

- Convenient online submission

Rigorous peer review

- Open access: articles freely available online

- High visibility within the field

- Retaining the copyright to your article

Submit your next manuscript at $\boldsymbol{\nabla}$ springeropen.com 